\title{
Seleksi dan Optimasi Karakter Fisik Bakteri Penghasil Fitase yang Diisolasi dari Sumber Air Panas di Guci, Tegal
}

\author{
C. S. Purwati ${ }^{1}$, Sajidan $^{2}$, A. Ratriyanto ${ }^{3}$ dan A. M. P. Nuhriawangsa ${ }^{3 *}$ \\ ${ }^{1}$ Jurusan Peternakan, Fakultas Pertanian, Universitas Veteran Bangun Nusantara, Sukoharjo. \\ ${ }^{2}$ Program Studi Pendidikan Biologi, Fakultas Keguruan dan Ilmu Pendidikan, Universitas Sebelas \\ Maret, Surakarta. \\ ${ }^{3}$ Program Studi Peternakan, Fakultas Pertanian, Universitas Sebelas Maret, Surakarta. \\ J1. Ir. Sutami 36 A Ketigan Surakarta \\ E-mail:adimagna67@yahoo.co.id
}

\begin{abstract}
ABSTRAK
Peneltian bertujuan untuk mengisolasi, menyeleksi dan mengkarakterisasi secara fisik bakteri penghasil fitase dari sumber air panas di Guci, Tegal. Isolasi dan pengkayaan bakteri menggunakan media Lurya Betani dengan substrat asam fitat sebesar 2\%. Ekstraksi secara ekstraseluler sehingga diperoleh ekstrak fitase kasar dan optimasi dengan melihat aktivitas relatif dengan melihat selisih produk yang dihasilkan. Bakteri penghasil fitase dapat diisolasi dari sumber air panas dari Guci, Tegal dengan aktivitas relatif tertinggi pada koloni AG2 dan AG2-1. Aktivitas relatif tertinggi pada temperatur $55^{\circ} \mathrm{C}, \mathrm{pH} 6$, waktu inkubasi 90 menit, konsentrasi substrat $3 \%$ dan kofaktor logam $\mathrm{Ca}^{2+}$ dengan konsentrasi $10^{-4} \mathrm{M}$. Bakteri penghasil fitase dapat diisolasi dari sumber air panas Guci, Tegal dan mempunyai karakter fisik tertentu.
\end{abstract}

Kata kunci: Bakteri, fitase, air panas, aktivitas relatif, karakter fisik

\section{Selection and Optimization of Physical Characters Phytase Producing-Bacteria Isolated from Hot Springs in the Guci, Tegal}

\section{ABSTRACT}

The aimed of this study to isolate, select and characterize physically phytase-producing bacteria from hot springs in the Guci, Tegal. Isolation and enrichment of bacteria using Lurya Betani media with $2 \%$ of phytic acid substrate. Extraction of extracellular phytase thus obtained extract coarse and optimization by loking at the relative activity at the difference in the resulting product. Phytaseproducing bacteria can be isolated from the hot springs of the Guci, Tegal with the highest relative activity in $A G 2$ and AG2-1 colonies. The highest relative activity at a temperature of $55^{\circ} \mathrm{C}, \mathrm{pH}$ 6, the incubation time of 90 minutes, the substrate concentration of $3 \%$ and a metal cofactor $\mathrm{Ca}^{2+}$ at a concentration of $10^{-4} \mathrm{M}$. Phytase-producing bacteria can be isolated from a hot spring in Guci, Tegal and have certain physical characteristics.

Keywords: Bacteria, hot spring, physical characteristics, phytase, relative activity

\section{PENDAHULUAN}

Hidrolisis asam fitat menjadi mioinositol dalam intestinum ayam broiler dipengaruhi oleh kandungan mineral $\mathrm{P}$ dan fitase (Zeller et al., 2015). Menurut Mittal et al. (2011) fitase juga ditambahakan pada pakan unggas selain ayam broiler sehingga dihasilkan derivat mio-inositol, fosfat organik dan elemen lainnya yang terikat pada asam fitat tersebut. Hal tersebut dapat menguntungkan kinerja hewan, kesehatan, kualitas daging dan kualitas telur unggas (Coewison et al., 2011).

Pada proses pembuatan pellet pakan unggas bahan pakan dipanaskan menggunakan suhu eksternal $60-90^{\circ} \mathrm{C}$ dan pada kondisi tersebut dapat memengaruhi 
aktivitas dari beberapa enzim yang dicampurkan dalam pakan tersebut (Spring et al., 1996). Mikroorganisme termofilik penting karena dapat menghasilkan produksi enzim yang stabil terhadap panas, sehingga dapat digunakan pada produk komersial tertentu (Mehta et al., 2016). Fitase yang digunakan pada proses pembuatan pakan harus stabil pada kondisi panas, karena tingginya temperatur pada saat pembuatan pakan (Kanpiengjai, 2013).

Beberapa bakteri penghasil fitase sudah dapat diisolasi dan dikarakterisasi dari daerah di Indonesia. Strain bakteri Eschericia coli, Bacillus subtilis dan Klebsiella pneumoniae sudah dapat diisolasi dan diaplikasikan pada ayam broiler (Sajidan et al., 2004). Bakteri penghasil fitase berkode AP-17 dari Kawah Ijen Banyuwang dapat diisolasi dan diduga merupakan kelompok Bacillus (Kusumadjaja et al., 2009). Hasil isolasi dari sumber abu vulkanik Merapi dihasilkan bakteri penghasil fitase Bacilllus cereus, Bacillus aryabhattai dan Bacillus cereus dengan karakter tertentu (Wulandari et al., 2011).

$\begin{array}{rrr}\text { Penelitian } & \text { bertujuan untuk } \\ \text { mengisolasi, }\end{array}$ mengkarakterisasi secara fisik bakteri penghasil fitase dari sumber air panas di Guci, Tegal, sehingga diharapkan dapat dihasilkan enzim termostabil yang dapat diaplikasikan untuk campuran pakan ternak komersial.

\section{MATERI DAN METODE}

Materi yang digunakan adalah sumber air panas Guci, media LB cair (per liter aquabides mengandung tripton $10 \mathrm{~g}$, ekstrak yeast $5 \mathrm{~g}$ dan $\mathrm{NaCl} 10 \mathrm{~g}$ ), LB padat (LB cair ditambah $15 \mathrm{~g}$ agar/liter), Na-fitat, Na-asetat, kofaktor ion $\mathrm{Ca}^{2+}$, ammonium molibdate, ammonium metavanadate dan aquades.

Isolat bakteri diperoleh dengan cara melarutkan $1 \mathrm{ml}$ air panas Guci dan air pada $1,5 \mathrm{ml} \mathrm{NaCl}$ fisiologis dan ditanam pada media LB padat selama 18 jam pada suhu $37^{\circ} \mathrm{C}$. Seleksi dilaksanakan untuk memperoleh isolat dengan aktivitas relatif tertinggi. Aktivitas relatif dihitung dengan melihat absorbansi terkoreksi sampel $\mathrm{x}$ 100\%. Absorbansi terkoreksi adalah absorbansi sampel dikurangi kontrol dibagi absorbansi sampel tertinggi dikurangi kontrol (Sajidan, 2002).

Kultur cair hasil inkubasi isolat dengan aktivitas relatif tertinggi disentrifugasi dengan kecepatan 5.000 rpm selama 5 menit dan supernatan diambil sebagai sumber ekstrak kasar fitase. Ekstrak enzim kasar dioptimasi untuk mengetahui karakter fisik yang meliputi temperatur, $\mathrm{pH}$, waktu inkubasi, konsentrasi substrat dan kofaktor logam. Aktivitas ekstrak kasar fitase diuji dengan $50 \mu \mathrm{l}$ enzim, $150 \mu \mathrm{l}$ susbtrat $(0,4 \%$ Na-fitat dalam $100 \mathrm{mM} \mathrm{Na}$ asetat) diinkubasi pada suhu $37^{\circ} \mathrm{C}$ selama 30 menit. Reaksi dihentikan dengan penambahan larutan STOP sebanyak $400 \mu 1$. (Larutan A: 2,352 g ammonium molibdat dalam $100 \mathrm{ml}$ aquades ditambah $2 \mathrm{ml}$ asam salpeter $\left(\mathrm{HNO}_{3}\right)$. Larutan $\mathrm{B}: 10 \mathrm{~g}$ ammonium metavanadat dalam $100 \mathrm{ml}$ aquades ditambah $1 \mathrm{ml} \quad 25 \% \quad \mathrm{NH}_{4} \mathrm{OH}$. Larutan STOP memcampur larutan A, larutan $\mathrm{B}$, asam salpeter dan aquades dengan perbandingan $=1,5: 1,5: 1: 2$ ). Warna kuning dari fosfomolibdat diukur dengan spektrofotometer pada $\lambda 415 \mathrm{~nm}$ (Sajidan, 2002).

\section{HASIL DAN PEMBAHASAN}

Hasil isolasi bakteri penghasil fitase berupa koloni yang diambil dari sumber air panas di Guci, Tegal tampak pada Gambar 1 yang menunjukan bahwa sumber air panas dari air Guci, Tegal mengandung bakteri penghasil fitase. Hal ini sesuai dengan beberapa penelitian yang dapat mengisolasi dari sumber air panas bakteri penghasil fitase. Bakteri penghasil fitase telah diisolasi dari daerah aliran sungai Gendol dan Boyong, Sleman, DIY dan sumber air panas di Gedongsongo, Ungaran, Jawa Tengah (Sajidan et al., 2010). Bakteri Anoxybacillus sp. MHW14 telah dapat diisolsasi dari sumber air panas di daerah Chiang Mai, 
Thailand (Kanpiengjai, 2013). Bacillus sp. DM12 dapat diisolasi dari sumber air panas di Dimand, Jiroft, Iran (Parhamfar et al., 2015). Thermomyces lanuginosus dapat diisolasi dari sumber air panas di Turki (Berikten dan Kivanc, 2014).

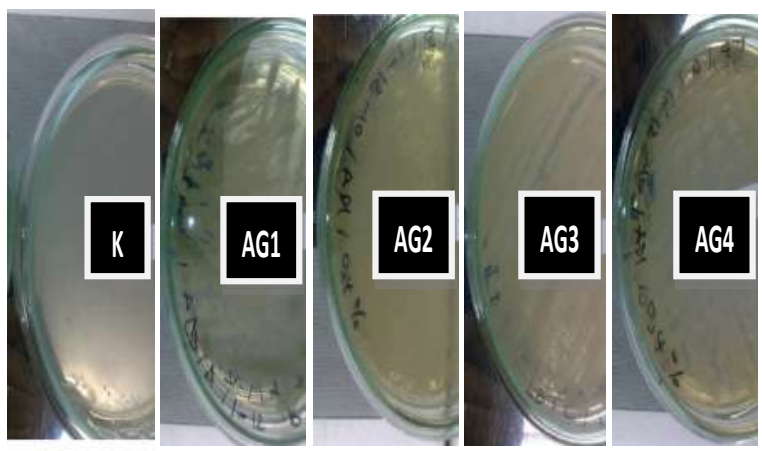

Gambar 1. Koloni bakteri yang diambil dari sumber air panas Guci dalam media LB dengan asam fitat $0,4 \%(\mathrm{~K}=$ kontrol, $\mathrm{AG} 1-4=$ koloni bakteri 1 sampai 4 )

Bakteri penghasil fitase yang telah diisolasi ternyata mempunyai aktivitas dalam menghidrolisis asam fitat dengan dilihat aktifitas relatifnya dan aktivitas tertinggi pada AG2 dan AG2-1(Gambar 2).

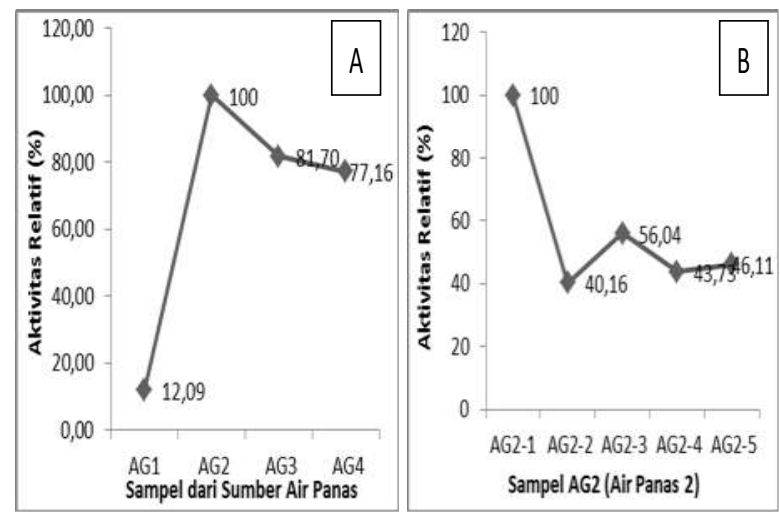

Gambar 2. Seleksi aktivitas relatif bakteri yang diambil dari sumber air panas Guci koloni AG1 sampai 4 (A) dan AG2-1 sampai 5 (B)

Hal ini sesuai dengan penelitian Kusumadjaja et al. (2009) bahwa Isolat AP-17 merupakan isolat penghasil fitase dengan aktivitas terbesar. Bakteri Anoxybacillus sp. MHW14 dari sumber air panas di daerah Chiang Mai, Thailand mampu memproduksi fitase (Kanpiengjai,
2013). Bacillus sp. DM12 dari sumber air panas di Dimand, Jiroft, Iran mempunyai aktivitas dalam menghidrolisis asam fitat (Parhamfar et al., 2015). Thermomyces lanuginosus dapat diisolasi dari sumber air panas di Turki dan mempunyai aktivitas fitase (Berikten dan Kivanc, 2014). Bakteri penghasil fitase koloni AG2-1 mempunyai aktifitas tertinggi pada temperatur $55^{\circ} \mathrm{C}$ (Gambar 3).

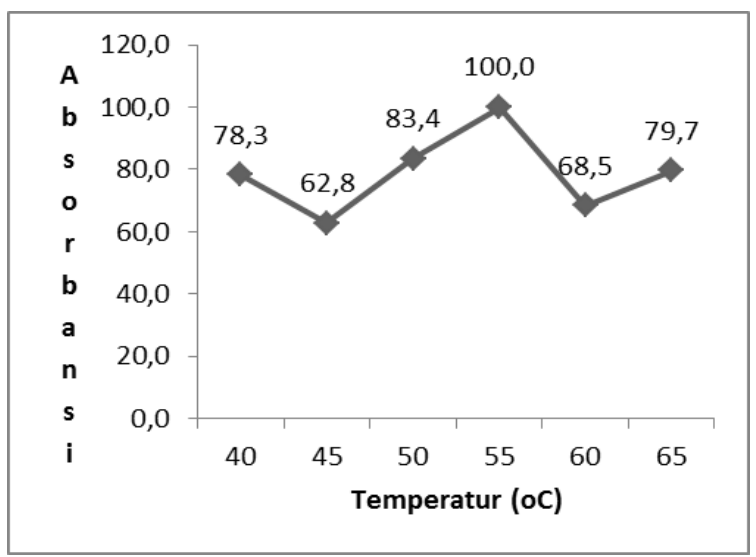

Gambar 3. Optimasi temperatur koloni bakteri AG2-1 (Absorbansi = aktivitas relatif)

Beberapa bakteri yang diambil dari sumber air panas mempunyai temperatur optimum yang berbeda. Bakteri Anoxybacillus sp. MHW14 dari sumber air panas di daerah Chiang Mai, Thailand mempuyai aktifitas optimum pada temperatur $\quad 45^{\circ} \mathrm{C}$ (Kanpiengjai, 2013). Bacillus sp. DM12 dari sumber air panas di Dimand, Jiroft, Iran mempunyai aktivitas optimum pada temperatur $55^{\circ} \mathrm{C}$ (Parhamfar et al., 2015). Thermomyces lanuginosus dapat dari sumber air panas di Turki mempunyai aktivitas optimum pada temperatur $55^{\circ} \mathrm{C}$ (Berikten dan Kivanc, 2014). Bakteri AG2-1 mempunyai aktifitas relatif tertinggi pada $\mathrm{pH} 6$ (Gambar 4).

Beberapa penelitian pada koloni bakteri penghasil fitase dari sumber air panas mempunyai $\mathrm{pH}$ optimum yang berbeda. Bakteri Anoxybacillus sp. MHW14 dari daerah Chiang Mai, Thailand mempuyai aktifitas optimum pada pH 7 (Kanpiengjai, 2013). Bacillus sp. DM12 dari Dimand, Jiroft, Iran mempunyai aktivitas optimum 
pada pH 4,5 (Parhamfar et al., 2015). Thermomyces lanuginosus dapat dari Turki mempunyai aktivitas optimum pada $\mathrm{pH}$ 7,5 (Berikten dan Kivanc, 2014).

Bakteri AG2-1 mempunyai aktifitas relatif tertinggi pada waktu inkubasi 90 menit (Gambar 5). Beberapa penelitian pada koloni bakteri penghasil fitase dari sumber air panas mempunyai waktu inkubasi optimum yang berbeda. Bakteri Anoxybacillus sp. MHW14 dari daerah Chiang Mai, Thailand mempuyai aktifitas optimum pada waktu inkubasi 30 menit (Kanpiengjai, 2013). Bacillus sp. DM12 dari Dimand, Jiroft, Iran mempunyai aktivitas optimum pada waktu inkubasi 30 menit (Parhamfar et al., 2015).

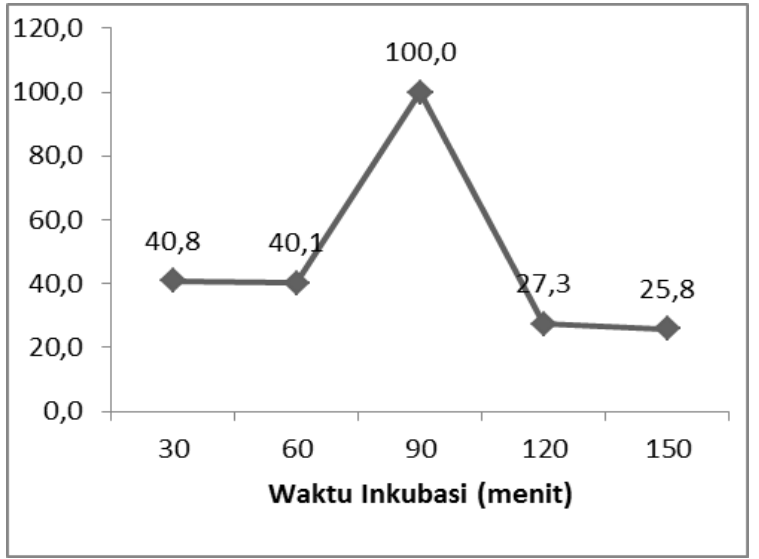

Gambar 5. Optimasi waktu inkubasi koloni bakteri AG2-1 (Absorbansi = aktivitas relatif)

Bakteri AG2-1 mempunyai aktifitas relatif tertinggi pada konsentrasi substrat 3\% (Gambar 6).

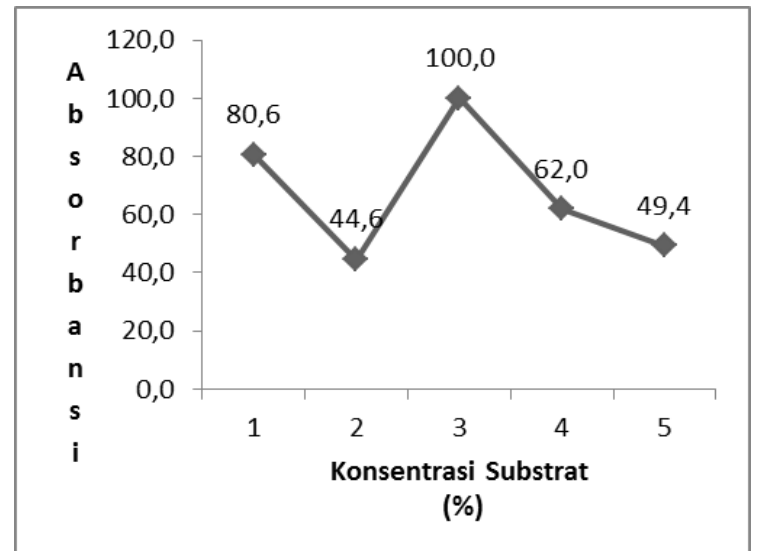

Gambar 6. Optimasi konsentrasi substrat koloni bakteri AG2-1 (Absorbansi = aktivitas relatif)
Beberapa penelitian pada koloni bakteri penghasil fitase dari sumber air panas mempunyai konsentrasi substrat optimum yang berbeda. Bakteri Anoxybacillus sp. MHW14 dari daerah Chiang Mai, Thailand mempuyai aktifitas optimum pada konsentrasi substrat 10,35\% bekatul padi (Kanpiengjai, 2013). Bacillus sp. DM12 dari Dimand, Jiroft, Iran mempunyai aktivitas optimum pada konsentrasi substrat $0,177 \mathrm{mM}$ Na-fitat (Parhamfar et al., 2015). Bakteri AG2-1 mempunyai aktifitas relatif tertinggi pada kofaktor logam $\mathrm{Ca}^{2+}$ (Gambar 7).

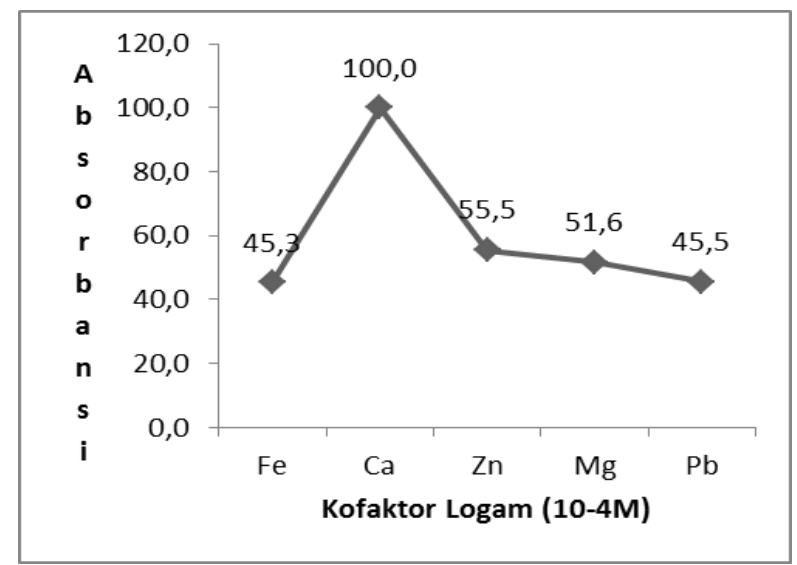

Gambar 7. Optimasi kofaktor logam koloni bakteri AG2-1 (Absorbansi = aktivitas relatif)

Beberapa penelitian pada koloni bakteri penghasil fitase dari sumber air panas mempunyai kofaktor logam yang berbeda. Bacillus sp. DM12 dari Dimand, Jiroft, Iran mempunyai aktivitas optimum pada kofaktor logam $\mathrm{Ca}^{2+} / \mathrm{CaCl}_{2}$ (Parhamfar et al., 2015). Thermomyces lanuginosus dapat dari Turki mempunyai aktivitas optimum pada kofaktor logam $\mathrm{Zn}^{2+} / \mathrm{ZnSO}_{4}$ (Berikten dan Kivanc, 2014).

\section{DAFTAR PUSTAKA}

Berikten, D. and M. Kivanc. 2014. Optimization of solid-state fermentation for phytase production by Thermomyces lanuginosus using response surface methodology. Journal Preparative Biochemistry and Biotechnology. 44(8): 834-848. 
Cowieson, A. J., P. Wilcock and M. R. Bedford. 2011. Super-dosing effects of phytase in poultry and other monogastrics. World's Poultry Science Journal. 67(2011): 225-235.

Kanpiengjai, A., K. Unban, R. Prathanaphon and C. Khanongnuch. 2013. Optimal medium and conditions for phytase production by thermophilic bacterium, Anoxybacillus sp. MHW14. Food and Applied Bioscience Journal. 1(3): 172-189.

Kusumadjaja, A. P., T. Budiati, N. N. T. Puspaningsih dan Sajidan. 2009. Screening Mikroorganisme Termofilik Penghasil Enzim Fitase yang Tumbuh di Kawah Ijen Banyuwangi. Indonesian Journal of Chemistry. 9(3):500-504.

Mehta, R., P. Singhal, H. Singh, D. Damle and A. K. Sharma. 2016. Insight into thermophiles and their widespectrum applications. Biotechnology. 6:81(1-9).

Mittal, A., G. Singh, V. Goyal, A. Yadav, K. R. Aneja, S. K. Gautam, N. K. Aggarwal. 2011. Isolation and biochemical characterization of acido-thermophilic extracellular phytase producing bacterial strain for potential application in poultry feed. Jundishapur Journal of Microbiology. 4(4):273-282.

Sajidan. 2002. Molekulare Characterisierung einer Phytase (Myo-inositol Hexakifosfate Hydrolase) und von Fosfatasen aus Bakterieisolaten Indoneschicher Reisfelder (Klebsiella pneumoniae). Dissertation. Institut fuer Biologie. Humboldt Universitat zu Berlin. Deutschland (Germany).

Sajidan, A. M. P. Nuhriawangsa, A. Ratriyanto and R. Greiner. 2010.
Isolation and Characterization of Phytase-Producing Bacteria from Extreme Regions in Indonesia. Laporan Hibah Kolaborasi Internasional. FKIP, UNS, Surakarta. Spring, P., K. E. Newman, C. Wenk, R. Messikommer, and M. V. Vranjes. 1996. Effect of pelleting temperature on the activity of different enzymes. Poultry Science. 75:357-361

Wulandari, R., Sajidan dan Suranto. 2011. Analisis Gen 16s rRNA pada Bakteri Penghasil Enzim Fitase. Naskah Publikasi Thesis. Program Studi Magister Biosains, Program Pasca Sarjana, Universitas Sebelas Maret, Surakarta.

Zahoor, S., H. M. Javed and M. E. Babar. 2016. Characterization of a novel hydrolytic enzyme producing Thermophilic bacterium isolated from the hot spring of Azad Kashmir-Pakistan. Brazilian Archives of Biology and Technology. 59(2016):1-13.

Zeller, E., M. Schollenberger, M. Witzig, Y. Shastak, I. Kuhn, L. E. Hoelzle and M. Rodehutscord. 2015. Interactions between supplemented mineral phosphorus and phytase on phytate hydrolysis and inositol phosphates in the small intestine of broilers. Poultry Science. 94:1018-1029. 